Print ISSN: 2233-4165 / Online ISSN: 2233-5382

doi:http://dx.doi.org/10.13106/ijidb.2018.vol9.no5.37.

\title{
Do Firm and Bank Level Characteristics Matter for Lending to Firms during the Financial Crisis?
}

\author{
Mihye Lee*
}

Received: April 15, 2018. Revised: April 30, 2018. Accepted: May 15, 2018.

\section{Abstract}

Purpose - This paper explores the determinants of bank lending to firms during and after the global financial crisis using firm- and bank-level data to answer the questions what caused the contraction of lending to firms despite the loosening monetary policy during this crisis period.

Research design, data, and methodology - We investigate the effects of the monetary policy that followed the global financial crisis on firms borrowing. We use a dynamic panel model to address how firms lending respond to monetary policy. The data are obtained from CRETOP and we consider the manufacturing sector for the analysis to control for unobserved heterogeneity such as industry-specific shocks.

Results - The findings from the empirical analysis suggest that both bank- and firm-level characteristics are significant determinants of bank lending. Especially, we find that corporate risk, measured by default risk, is one of the key factors that led to a decline in lending during the crisis.

Conclusions - This paper shows that companies borrow more from liquid banks, and high bank capital can also contribute to an increase in a firm's borrowing from banks. Especially, the results confirm that the default rate measured at the firm level has increased during and after the global financial crisis, which implies that default risk interplays with other firm and bank-level characteristics.

Keywords: Bank Lending, Financial Crisis, Monetary Policy, Small and Medium Enterprises, Default Risk.

JEL Classifications: G32, G38, G21.

\section{Introduction}

The global financial crisis that which spread began in 2007 from the United States had a significant impact on the financial markets and economic activities around the world. and Korea is one of the countries which has was also hit severely hit by from the recent crisis. To soften its effect on the Korean economy, the Bank of Korea has gradually cut the policy rate, and the expansionary monetary policy has resulted in the decline in the interest rates on loans. The central bank also expanded its lending program to small and medium enterprises (SMEs) to provide liquidity in support of their activities. Despite these efforts carried on by the central bank, the growth rate on loans to corporates has slowed down, and the lending to SMEs has shrunk in 2010. This raises questions about what caused the contraction of

\footnotetext{
* Assistant Professor, Division of Economics and Information Statistics, Kangwon National University, Korea.

Tel: +82-63-250-6123, E-mail: mihyelee@kangwon.ac.kr
}

lending to firms despite the loosening monetary policy during this crisis period. Understanding the determinants of this phenomenon would help policy-makers improve their strategy in case of another crisis.

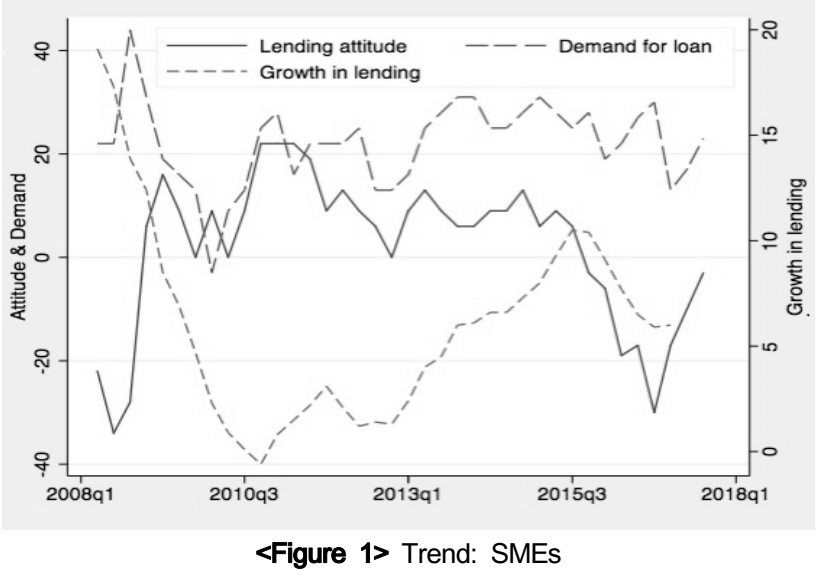


To answer this question, we try to identify the crucial determinants of the size of loans or the borrowing capacity of firms using firm- and bank-level data. We first try to determine such factors through empirical analysis, and, then, we investigate whether those factors have significantly changed during the sample period using survey data. Whenever it comes to analyze the bank lending to firms, the natural question is whether supply or demand factors determine changes in lending. For instance, a company can change the amount of borrowing from financial institutions in the presence of lower (higher) demand for loans or when financial institutions are less (more) reluctant to lend than before, or both. One possible way to solve this identification issue is using data on firms demand for loans and banks lending attitude towards firms. We obtained data on the lending attitude, demand for loans, and growth in lending from the Bank of Korea and examined the trends in the demand and supply of loans based on these data.

<Figure 1> and <Figure 2> show the trend in banks lending attitude towards firms by its sizes, firms demand for loans, and growth in lending for SMEs and large firms, respectively. The information regarding the lending attitude is obtained from a survey conducted by the Bank of Korea addressing financial institutions and banks, and the relative index clarifies whether banks apply strict loan standards or not. If the value of the index is above zero, banks are willing to loosen their loan standards to firms.

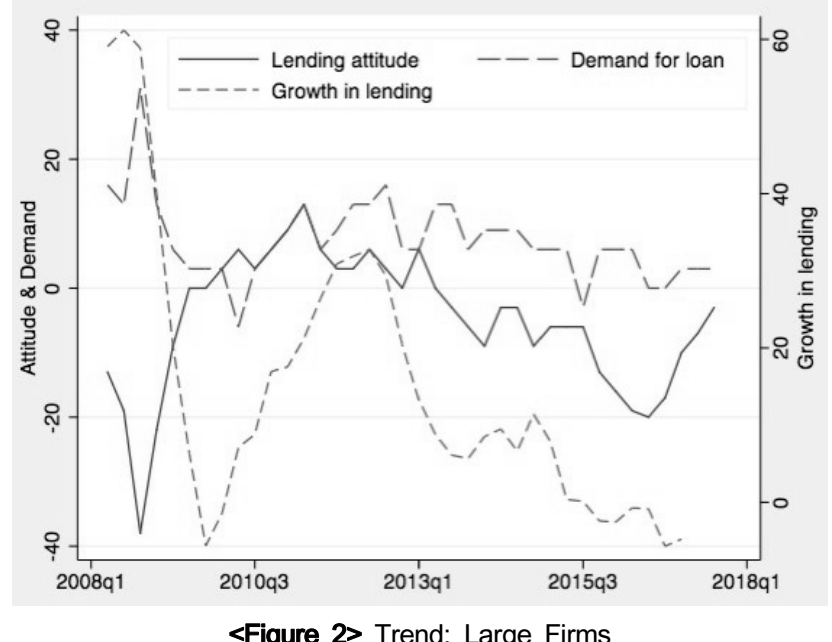

The remainder of this paper is organized as follows. Section 2 summarizes the related literature. Section 3 provides some detailed information on the data used for the empirical analysis and presents the empirical strategy and results. Section 4 concludes.

\section{Related Literature}

There are several strands of literature that examine the impact of recent financial crisis on economy. For instance, Liu and Sohn(20115) investigate the risk price based on the recent global financial crisis in the Korean stock distribution. Banna et al.(2017) study the effect of the global financial crisis and other factors on the efficiency of banks based on Bangladesh bank-level data.

The existing literature has primarily focused on the channels of transmission of monetary policy, from the interest rate channel to the credit channel. In particular, the credit channel emphasizes the information asymmetry between the lender and the borrower and has an essential role in understanding the amplification mechanism of the monetary policy. Bernanke and Gertler(1995) examine this view based on the balance sheet channel and bank lending channel.

Many empirical and theoretical studies investigated the importance of the credit channel at the firm level. For instance, Gertler and Gilchrist(1994) show that small firms are more affected by the lending channel since they have limited access to the capital market.

Empirical studies are scarce in the existing literature due to the limited availability of firm-level data on lending. Only a few studies used this type of information in the case of Korea. Shin(2010) analyzes firm-level data to investigate whether the monetary policy has a significant impact on companies through changes in investment. The study focuses on 736 manufacturing firms and shows that the effect of the monetary policy on firms varies depending on their characteristics, such as firm size. Shin and Kim(2007) also show that small companies are more responsive to monetary policy due to the lack of alternative sources of financing other than bank lending.

In contrast with the existing literature, we investigate the determinants of bank lending to firms using extensive firm-level data. In particular, we examine whether the bank lending channel significantly explains the changes in bank lending during the recent global financial crisis. After the crisis, lending to firms, especially SMEs, did not increase in response to the expansionary and unconventional monetary policy aimed at providing credit to companies.

This phenomenon raises a question about the existence of a bank lending channel during the financial crisis. We explored this issue using firm- and bank-level data to control for firm heterogeneity and credit supply by banks. Our result will shed some light on the effects of the monetary policy during the crisis and will help policy-makers have a better understanding of the propagation mechanism of the monetary policy. 


\section{Empirical Strategy and Identification}

In this section, we investigate the effects of the monetary policy that followed the global financial crisis on firms borrowing. Using both bank- and firm-level data, we address how firms lending respond to monetary policy and whether bank-level characteristics play a significant role in determining their lending to firms.

The data are obtained from CRETOP, a business credit report on Korean businesses maintained by Korea Enterprise Data (KED). The database includes information on both listed and unlisted firms and provides information on the financial statement of individual companies along with other firm-level characteristics such as recent credit ratings, history, management, etc. Most importantly, the database contains information on a firm's lending from each bank, and this information enables us to examine the role played by bank-level characteristics in determining firms lending. In other words, most firm-level data contains information on the financial statement and the amount of lending from banks, which makes it difficult to assess the role of banks as a determinant of firm borrowing. In contrast, the database used in this study provides information on how much a firm borrowed from each bank. As a result, we can combine this information with banks characteristics, considered as determinants of firm lending.

The database also contains firm-level characteristics, such as the incorporation date and number of employees, along with firms financial statements. We also obtained bank information from the financial supervisory service and included it in the empirical analysis. We only consider the manufacturing sector for the analysis to control for unobserved heterogeneity such as industry-specific shocks. As a result, the number of firms in the database is 50,035 , observed from 2008 to 2011 . In the sample, $3.2 \%$ of companies are large, $11.9 \%$ are medium-sized, and $84.9 \%$ are small firms.

\subsection{Empirical Strategy}

In this section, we investigate the factors that contributed to the decline or changes in bank lending to firms after the global financial crisis. The empirical identification of these factors is challenging since lending could decrease because banks are more cautious in giving loans to firms an/or companies do not need to borrow. <Figure 1> shows that SMEs have a positive demand for loans in the sample period but their lending from banks did not grow as much as their demand or financial institutes attitude to lending. We interpret the survey results as evidence of a positive demand for loans for SMEs. Therefore, we examine the determinants of firm lending based on firms characteristics and bank-side conditions along with the policy rate, which is closely related to interest rates.
As a baseline model, we use a dynamic panel model, and we define the size of bank lending as the sum of the borrowings from each bank. The estimated equation is of the following:

$$
\text { Lending }_{i, t}=\beta_{1} \text { Lending }_{i, t-1}+\beta_{2} X_{i, t}+\beta_{3} \text { call }_{t}+\epsilon_{i, t}
$$

where Lending $_{i, t}$ denotes the logarithm of bank lending, defined as the sum of all lending activities from all banks. $X_{i, t}$ are firm-specific characteristics and call $_{t}$ is the policy rate.

We also control for firm-specific characteristics as determinants of their borrowing from banks following Jimnez et al.(2012), Fukuda et al.(2006). We use the logarithm of total assets as a proxy for firm size. Firm size is an essential indicator not only because it is related to the size of lending from a bank, but it also indicates whether a firm has alternative sources of borrowing. For instance, it is well known that large firms or large and publicly listed companies raise funds by issuing equities and bonds. Therefore, it is likely that SMEs depend more on bank lending than large firms due to their limited access to the capital market. Besides firm size, we also control for firm's age. Rajan and Zingales(1998) document that a company needs more funding at its initial stage due to the initial investment. Firm profitability, interest coverage ratio as a proxy of the default risk, and the ratio of the tangible assets to total assets are also included in the model as independent variables. As a measure of the default risk, we define a dummy variable equal to 1 if the interest coverage ratio is less than 0 , meaning that a firm faces default risk, and 0 otherwise.

As a determinant of the lending from banks, we also consider a firm's collateral value, which is defined as the ratio of tangible assets to total assets.

We expect the coefficient on firm size to have a negative coefficient if a firm does not only depend on bank lending and has alternative ways to raise funds. The sign will be positive if a company borrows more from banks firms or the access to bank lending is rather straightforward The collateral value has a positive effect on bank lending, and we expect a company to have larger loan demand on its earlier stage.

In contrast with the existing empirical studies, we use bank-level characteristics as controls for the supply side of a loan. Two variables are considered, bank liquidity and capital ratio. From the firm's point of view, lending corresponds to the sum of the lending activities from individual banks, and we calculate the weighted sum of the liquidity and capital ratio based on the ratio of lending from an individual bank to total lending. More liquid banks with enough liquidity are more likely to supply credit to firms. Bank capital would have a similar effect on lending as bank liquidity.

As an additional independent variable, we include in the model the degree of concentration of loan to banks. We 
calculate the degree of concentration based on the Herfindahl index. A higher index means that total lending is concentrated among a small number of firms or a firm borrows heavily from a few banks. This index may represent the relationship banking since it shows how many banks are involved in a firm's lending activity. Firms can borrow from financial institutions, such as banks, and non-financial institutions when the former apply more strict lending standard or higher financing costs.

Finally, we need to consider the cost of borrowing, which is represented by the interest rate. We use the policy rate set by the Bank of Korea as a proxy of the interest rate since the available data does not contain any information on the interest rate of individual loans.

$<$ Table $1>$ shows the summary of the variable definitions and expected sign for each variable used in the empirical analysis.

\subsection{Empirical Results}

$<$ Table 2> reports the baseline empirical results obtained including in the sample both large companies and SMEs. The coefficients on firm size (columns (1) to (4)) are positive and statistically significant, which means that larger firms tend to have more bank lending or that SMEs borrow less than large firms. This result holds when we only include SMEs in the empirical analysis, as shown in <Table 3>. As expected, firm's age has a negative effect on firms lending, which suggests that young companies need more bank lending, in line with the findings from Rajan and Zingales(1998). The coefficients on firm size and age confirm the conclusions from the existing literature, that is, small and young firms require more bank lending. Firms default risk, measured as the interest coverage ratio, also has the expected sign: the negative coefficient indicates that lending decreases with firms default risk (Benno et al., 2017). The positive and statistically significant coefficient on firms collateral value shows that bank lending to firms increases with firms collateral value. These results are consistent with the existing literature.

<Table 1> Definition of Variables

\begin{tabular}{|c|c|c|}
\hline Variable & Definition & Expected Sign \\
\hline $\ln ($ assets $)$ & Size of Firm & + or - \\
\hline $\ln (1+$ age $)$ & Firm's Age & + \\
\hline $\begin{array}{c}\text { Tangible Asset } \\
\text { Total Asset }\end{array}$ & Collateral Value & + \\
\hline ROA $\left(\frac{\text { Profit }}{\text { TotalAsset }}\right.$ & Profitability & - \\
\hline DR1) & Default Risk & + \\
\hline Bank Cap2) & Weighted Sum of Bank Capital Ratio & + \\
\hline Bank Liq3) & Weighted Sum of Bank Liquidity Ratio & + or - \\
\hline h4) & Concentration of Loans & + or - \\
\hline call & The ratio of borrowing from Non-financial institution & + or - \\
\hline Ratio5) & Policy Rate & \\
\hline
\end{tabular}

Note: 1) Dummy variable. It is denoted 1 if interest coverage ratio is less than 1 ; otherwise 0.

2) Bank Cap $=\sum_{j=1}^{7} \frac{\text { Borrowing }}{\text { Bankjeapital Ratio }}$

3) Bank Liq $\left(=\frac{\text { Liquid Asset }}{\text { Liquid Dbet }}\right)^{\prime}$ s weighted sum

4) $h=\sum_{j=1}^{7}\left(\frac{\text { Borrowing }_{j}}{\text { Total Borrowing }}\right)^{2}, 0 \leq h \leq 1$

5) Ratio=(Borrowing from Non-bank Financial Institutions/Total Borrowing $)^{2}$

<Table 2> Baseline Results

\begin{tabular}{|c|c|c|c|c|}
\hline & (1) & (2) & (3) & (4) \\
\hline \multirow{2}{*}{ Intercept } & $-3.89^{\star \star \star *}$ & $-3.86^{\star \star \star}$ & $-3.9^{\star \star \star}$ & $-3.69^{\star \star \star}$ \\
\hline & $(0.16)$ & $(0.16)$ & $(0.16)$ & $(0.16)$ \\
\hline \multirow{2}{*}{ Lending $_{i, t-1}$} & $0.41^{\star \star *}$ & $0.41^{\star \star \star}$ & $0.41^{\star \star \star}$ & $0.41^{\star \star \star}$ \\
\hline & $(0.01)$ & $(0.01)$ & $(0.01)$ & $(0.01)$ \\
\hline \multirow{2}{*}{$\ln ($ assets $)$} & $0.87^{\star \star \star}$ & $0.87^{\star \star \star}$ & $0.87^{\star \star \star}$ & $0.86^{\star \star \star}$ \\
\hline & $(0.01)$ & $(0.01)$ & $(0.01)$ & $(0.01)$ \\
\hline \multirow{2}{*}{$\ln (1+$ age $)$} & -0.45 & $-0.45^{\star \star \star}$ & $-0.46^{\star \star *}$ & $-0.46^{\star \star \star}$ \\
\hline & $(0.04)$ & $(0.04)$ & $(0.04)$ & $(0.04)$ \\
\hline
\end{tabular}




\begin{tabular}{|c|c|c|c|c|}
\hline \multirow{2}{*}{$\frac{\text { Tangible Asset }}{\text { Total Asset }}$} & $0.00^{\star \star \star}$ & $0.00^{* * *}$ & $0.00^{* \star *}$ & $0.00^{* * *}$ \\
\hline & $(0.00)$ & $(0.00)$ & $(0.00)$ & $(0.00)$ \\
\hline \multirow{2}{*}{$\frac{\text { Profit }}{\text { TotalAsset }}$} & $-0.1^{* \star *}$ & $-0.1^{* \star \star}$ & $-0.1^{\star \star \star}$ & $-0.1^{\star \star \star}$ \\
\hline & $(0.00)$ & $(0.00)$ & $(0.00)$ & $(0.00)$ \\
\hline \multirow{2}{*}{ DR } & & $-0.05^{\star \star \star}$ & $-0.05^{\star \star \star}$ & $-0.04^{\star \star \star}$ \\
\hline & & $(0.01)$ & $(0.01)$ & $(0.01)$ \\
\hline \multirow{2}{*}{ Bank Cap } & & & $0.01^{* \star *}$ & $0.09^{\star * \star}$ \\
\hline & & & $(0.00)$ & $(0.00)$ \\
\hline \multirow{2}{*}{ Bank Liq } & & & 0.00 & $0.01^{* \star *}$ \\
\hline & & & $(0.00)$ & $(0.00)$ \\
\hline \multirow{2}{*}{$\mathrm{h}$} & & & & $-0.82^{\star \star *}$ \\
\hline & & & & $(0.03)$ \\
\hline \multirow{2}{*}{ call } & $-0.02^{* * *}$ & $-0.02^{\star \star *}$ & $-0.02^{\star \star \star}$ & $-0.04^{\star * *}$ \\
\hline & $(0.01)$ & $(0.01)$ & $(0.01)$ & $(0.01)$ \\
\hline Wald Statistics & $16,747.37$ & $16,741.65$ & $16,749.19$ & $17,576.93$ \\
\hline p-value & {$[0.00]$} & {$[0.00]$} & {$[0.00]$} & {$[0.00]$} \\
\hline group & \multicolumn{4}{|c|}{41,794} \\
\hline obs & \multicolumn{4}{|c|}{77,455} \\
\hline
\end{tabular}

Note: ( ) standard errors, ${ }^{* *}, * *,{ }^{*}$ denote $1 \%, 5 \%, 10 \%$ significance levels

1) It tests whether the estimates coefficients are jointly equal to zero

The coefficient on firm profitability is negative and statistically significant. This result contradicts that of existing empirical studies, which predict a positive relationship between firm's profitability and bank lending. The existing literature shows that companies require more bank lending for further production expansion and additional investment, thus resulting in increasing bank lending. Our result is likely to be driven by the sample period, which begins with the global financial crisis. There has been a recession in this period, and uncertainty has significantly increased. As result, firms were more reluctant to invest, which implied a decline in the demand for loans. On the other hand, this also means that low profit companies demanded more loans due to the lack of internal sources of funding.

Firm-level characteristics are essential determinants of bank lending to firms, but bank level characteristics are also important factors to be considered. For instance, banks need to cut or reduce their lending to firms when they lack liquidity. In addition, addressing bank characteristics also enables us to identify the determinants of bank lending to controlling for the bank supply of loans to companies. In other words, this helps us determine whether firm-level characteristics or interest rates play a significant role in deciding the amount of bank lending besides bank supply.

With respect to bank-level characteristics, we include in the analysis the weighted sum of bank liquidity and capital ratio as independent variables. We also consider how lending is concentrated among banks as a proxy for relationship banking. Columns (3) and (4) in <Table 2> show the results of the analysis including those variables. As expected, the coefficients on higher bank liquidity ratio and capital ratio have a statistically significant and positive sign, which means that banks with higher liquidity or capital ratio are likely to lend more to firms or supply more credit. Column (4) shows the result including the index " $h$ ", which indicates how a firm's lending is concentrated to banks; the coefficient on the index is negative. It is possible to interpret this result as evidence of the fact that having a close tie with a few main banks does not help firms raise funding. In other words, this negative coefficient indicates that a firm does not benefit from relationship banking in this period. This result can be also interpreted as follows: a firm in financial distress has difficulty in establishing a new line of credit, and this results in firms borrowing from a few major banks and having lower lines of credit. In this respect, our findings are different from $\mathrm{Kim}$ and $\mathrm{Kim}(2007)$, which also investigate relationship banking in Korea. We further investigate this issue using the interaction term between the index " $h$ and a firm's default risk. Last, we include the policy rate in the analysis, and we show that it has a negative effect on a firm's borrowing.

What we have observed so far is that a firm's size and collateral value have a positive relationship with its borrowing from banks, and older and profitable companies tend to borrow less. Default risk also has a negative effect on lending. We also find that bank-level characteristics play a significant role; in particular, banks with more liquidity and capital guarantee higher levels of corporate lending. Those results are based on the whole sample.

In the next step of the analysis, we limit our attention to SMEs. <Table $3>$ shows the results based on SMEs. Most results are consistent with the previous findings. However, the coefficient on collateral value becomes larger compared to the results in <Table 2>. This means that collateral is more important to SMEs than large firms. 
<Table 3> Baseline Result: SMEs

\begin{tabular}{|c|c|c|c|c|}
\hline & (1) & (2) & (3) & (4) \\
\hline \multirow{2}{*}{ Intercept } & $-2.93^{\star * *}$ & $-2.92^{* \star *}$ & $-2.96^{* * *}$ & $-2.75^{\star \star *}$ \\
\hline & $(0.15)$ & $(0.15)$ & $(0.15)$ & $(0.15)$ \\
\hline \multirow{2}{*}{ Lending $_{t-1}$} & $0.38^{\star * *}$ & $0.39^{\star \star \star}$ & $0.39^{\star \star *}$ & $0.38^{\star * *}$ \\
\hline & $(0.01)$ & $(0.01)$ & $(0.01)$ & $(0.01)$ \\
\hline \multirow{2}{*}{$\ln ($ assets $)$} & $0.79^{* * *}$ & $0.79^{* * *}$ & $0.79^{\star \star \star}$ & $0.78^{\star * *}$ \\
\hline & $(0.01)$ & $(0.01)$ & $(0.01)$ & $(0.01)$ \\
\hline \multirow{2}{*}{$\ln (1+$ age $)$} & $-0.34^{\star \star *}$ & $-0.34^{\star \star *}$ & $-0.35^{\star \star \star}$ & $-0.35^{\star \star \star}$ \\
\hline & $(0.04)$ & $(0.04)$ & $(0.04)$ & $(0.04)$ \\
\hline TangibleAsset & $1.04^{* * *}$ & $1.03^{\star * \star}$ & $1.04^{\star \star *}$ & $1.04^{\star * *}$ \\
\hline TotalAsset & $(0.03)$ & $(0.03)$ & $(0.03)$ & $(0.03)$ \\
\hline Profit & $-0.08^{\star * *}$ & $-0.08^{\star \star \star}$ & $-0.08^{\star \star *}$ & $-0.08^{\star * *}$ \\
\hline TotalAsset & $(0.00)$ & $(0.00)$ & $(0.00)$ & $(0.00)$ \\
\hline \multirow{2}{*}{ DR } & & $-0.04^{\star \star \star}$ & $-0.04^{\star \star \star}$ & $-0.03^{\star * \star}$ \\
\hline & & $(0.01)$ & $(0.01)$ & $(0.01)$ \\
\hline \multirow{2}{*}{ Bank Cap } & & & $0.01^{* \star *}$ & $0.08^{* * *}$ \\
\hline & & & $(0.00)$ & $(0.00)$ \\
\hline \multirow{2}{*}{ Bank Liq } & & & 0.00 & $0.01^{* * *}$ \\
\hline & & & $(0.00)$ & $(0.00)$ \\
\hline \multirow{2}{*}{$\mathrm{h}$} & & & & $-0.76^{* \star *}$ \\
\hline & & & & $(0.03)$ \\
\hline \multirow{2}{*}{ call } & $-0.02^{* *}$ & $-0.02^{* *}$ & $-0.02^{* * *}$ & $-0.03^{\star \star *}$ \\
\hline & $(0.01)$ & $(0.01)$ & $(0.01)$ & $(0.01)$ \\
\hline Wald statistics & $19,737.86$ & $19,729.36$ & $19,750.00$ & $20,539.64$ \\
\hline $\mathrm{p}$-value & [0.00] & {$[0.00]$} & {$[0.00]$} & {$[0.00]$} \\
\hline group & \multicolumn{4}{|c|}{40,594} \\
\hline obs & \multicolumn{4}{|c|}{75,322} \\
\hline
\end{tabular}

In the next step of the empirical analysis, we include the interaction term between $\mathrm{h}$ and default risk. As mentioned earlier, the negative coefficient on $h$ can be driven by two possible sources, and we explore those two possibilities including the interaction term. The intuition behind this interaction term is straightforward. Let us assume the existence of two firms with the same level of $h$, and they only have different default risks. If the interaction term is negative, it means that the risky firm's borrowing from banks cannot exceed the borrowing level of the safe company with the same level of $h$. If the coefficient on the interaction term is not statistically significant, this means that $h$ does not have an additional impact on lending through default risk, suggesting the absence of a significant impact of relationship banking during this period. We also introduce the interaction term between a firm's default risk and bank liquidity, and between a firm's default risk and bank capital (<Table 4>). Column (1) and (3) in <Table 4> report the results for the whole sample. The sign on the interaction term between $h$ and default risk is positive and significant, which indicates that firms with higher default risk can increase their borrowing. This is also true when we only include SMEs in the analysis. This result suggests that companies with substantial default risk could benefit from relationship banking during the sample period. The results also show that firms can increase their borrowing even in the presence of substantial default risk when banks are liquid. On the other hand, the interaction term between default risk and bank capital has a negative sign. These results are consistent both in the whole sample and SMEs subsample.

<Table 4> Baseline Result including the interaction terms with policy rate I

\begin{tabular}{|c|c|c|c|c|c|c|}
\hline & \multicolumn{3}{|c|}{ Whole Sample } & \multicolumn{3}{|c|}{ SMEs } \\
\hline & (1) & (2) & (3) & (1) & (2) & (3) \\
\hline \multirow{2}{*}{ Intercept } & $-3.68^{\star \star *}$ & $-3.63^{\star \star *}$ & $-3.65^{\star \star \star}$ & $-2.75^{\star \star \star}$ & $-2.7^{\star * \star}$ & $-2.72^{\star \star \star}$ \\
\hline & $(0.16)$ & $(0.16)$ & $(0.16)$ & $(0.15)$ & $(0.15)$ & $(0.15)$ \\
\hline \multirow{2}{*}{ Lending $_{t-1}$} & $0.41^{* \star *}$ & $0.4^{* * *}$ & $0.41^{* \star *}$ & $0.38^{\star \star \star}$ & $0.38^{\star \star \star}$ & $0.38^{\star \star *}$ \\
\hline & $(0.01)$ & $(0.01)$ & $(0.01)$ & $(0.01)$ & $(0.01)$ & $(0.01)$ \\
\hline \multirow{2}{*}{$\ln ($ assets $)$} & $0.86^{\star \star \star}$ & $0.86^{\star \star \star}$ & $0.86^{\star \star \star}$ & $0.78^{\star \star *}$ & $0.78^{\star \star \star}$ & $0.78^{\star \star \star}$ \\
\hline & $(0.01)$ & $(0.01)$ & $(0.01)$ & $(0.01)$ & $(0.01)$ & $(0.01)$ \\
\hline \multirow{2}{*}{$\ln (1+$ age $)$} & $-0.46^{\star \star \star}$ & $-0.47^{\star \star *}$ & $-0.48^{\star \star \star}$ & $-0.35^{\star \star \star}$ & $-0.36^{\star \star \star}$ & $-0.37^{\star \star \star}$ \\
\hline & $(0.04)$ & $(0.04)$ & $(0.04)$ & $(0.04)$ & $(0.04)$ & $(0.04)$ \\
\hline \multirow{2}{*}{$\frac{\text { TangibleAsset }}{\text { TotalAsset }}$} & $0.00^{\star \star \star}$ & $0.00^{* \star \star}$ & $0.00^{* \star *}$ & $1.04^{\star \star *}$ & $1.05^{\star \star \star}$ & $1.05^{\star \star \star}$ \\
\hline & $(0.00)$ & $(0.00)$ & $(0.00)$ & $(0.03)$ & $(0.03)$ & $(0.03)$ \\
\hline \multirow{2}{*}{$\frac{\text { Profit }}{\text { TotalAsset }}$} & $-0.1^{* \star *}$ & $-0.1^{* \star *}$ & $-0.1^{* \star *}$ & $-0.08^{\star \star *}$ & $-0.08^{\star \star \star}$ & $-0.08^{* * *}$ \\
\hline & $(0.00)$ & $(0.00)$ & $(0.00)$ & $(0.00)$ & $(0.00)$ & $(0.00)$ \\
\hline \multirow{2}{*}{$\mathrm{DR}$} & $-0.07^{* \star *}$ & $-0.07^{\star \star *}$ & $-0.07^{\star \star \star}$ & $-0.05^{\star \star *}$ & $-0.06^{\star \star *}$ & $-0.06^{\star \star \star}$ \\
\hline & $(0.01)$ & $(0.01)$ & $(0.01)$ & $(0.01)$ & $(0.01)$ & $(0.01)$ \\
\hline \multirow{2}{*}{ Bank Cap } & $0.09^{* \star *}$ & $0.05^{\star \star \star}$ & $0.07^{* * *}$ & $0.08^{\star * *}$ & $0.05^{\star \star *}$ & $0.06^{\star * *}$ \\
\hline & $(0.00)$ & $(0.01)$ & $(0.01)$ & $(0.00)$ & $(0.01)$ & $(0.01)$ \\
\hline \multirow{2}{*}{ Bank Liq } & $0.01^{* \star *}$ & $0.05^{* \star *}$ & $0.04^{* * *}$ & $0.01^{* \star *}$ & $0.05^{\star \star *}$ & $0.04^{\star \star *}$ \\
\hline & $(0.00)$ & $(0.01)$ & $(0.01)$ & $(0.00)$ & $(0.01)$ & $(0.01)$ \\
\hline \multirow{2}{*}{$\mathrm{h}$} & $-0.82^{* \star *}$ & $-0.43^{* * *}$ & $-0.33^{\star \star *}$ & $-0.77^{\star \star *}$ & $-0.36^{\star \star \star}$ & $-0.24^{\star \star *}$ \\
\hline & $(0.03)$ & $(0.06)$ & $(0.07)$ & $(0.03)$ & $(0.05)$ & $(0.07)$ \\
\hline \multirow{2}{*}{$h^{*} \mathrm{DR}$} & $0.08^{\star *}$ & $0.08^{\star *}$ & $0.08^{\star *}$ & $0.08^{\star *}$ & $0.08^{\star *}$ & $0.08^{\star *}$ \\
\hline & $(0.03)$ & $(0.03)$ & $(0.03)$ & $(0.03)$ & $(0.03)$ & $(0.03)$ \\
\hline
\end{tabular}




\begin{tabular}{|c|c|c|c|c|c|c|}
\hline & \multicolumn{3}{|c|}{ Whole Sample } & \multicolumn{3}{|c|}{ SMEs } \\
\hline & (1) & (2) & (3) & (1) & (2) & (3) \\
\hline \multirow{2}{*}{ hBank Liq } & & $-0.06^{* * *}$ & $-0.04^{* * *}$ & & $-0.06^{* * *}$ & $-0.04^{\star * *}$ \\
\hline & & $(0.01)$ & $(0.01)$ & & $(0.01)$ & $(0.01)$ \\
\hline \multirow{2}{*}{ hBank Cap } & & & $-0.03^{\star * *}$ & & & $-0.03^{* * *}$ \\
\hline & & & $(0.01)$ & & & $(0.01)$ \\
\hline \multirow{2}{*}{ call } & $-0.04^{\star * *}$ & $-0.03^{\star * *}$ & $-0.03^{\star \star \star}$ & $-0.03^{\star * *}$ & $-0.02^{\star * *}$ & $-0.02^{\star \star \star}$ \\
\hline & $(0.01)$ & $(0.01)$ & $(0.01)$ & $(0.01)$ & $(0.01)$ & $(0.01)$ \\
\hline Wald statistics & $17,581.80$ & $17,747.98$ & $17,740.67$ & $20,543.49$ & $20,721.21$ & $20,702.98$ \\
\hline p-value & {$[0.00]$} & {$[0.00]$} & {$[0.00]$} & {$[0.00]$} & {$[0.00]$} & {$[0.00]$} \\
\hline group & \multicolumn{3}{|c|}{41,795} & \multicolumn{3}{|c|}{40,594} \\
\hline obs & \multicolumn{3}{|c|}{77,456} & \multicolumn{3}{|c|}{75,322} \\
\hline
\end{tabular}

<Table 5> Baseline Result including the interaction terms with policy rate II

\begin{tabular}{|c|c|c|c|c|c|c|}
\hline & \multicolumn{3}{|c|}{ Whole Sample } & \multicolumn{3}{|c|}{ SMEs } \\
\hline & (1) & (2) & (3) & (1) & $(2)$ & (3) \\
\hline \multirow{2}{*}{ Intercept } & $-2.41^{* \star *}$ & $-2.41^{* \star *}$ & $-2.46^{* * *}$ & $-1.53^{* * *}$ & $-1.53^{\star * *}$ & $-1.58^{* * *}$ \\
\hline & $(0.14)$ & $(0.14)$ & $(0.14)$ & $(0.13)$ & $(0.13)$ & $(0.13)$ \\
\hline \multirow{2}{*}{ Lending $_{t-1}$} & $0.34^{\star \star *}$ & $0.34^{* \star *}$ & $0.34^{\star \star *}$ & $0.32^{* * *}$ & $0.32^{\star \star *}$ & $0.32^{* \star *}$ \\
\hline & $(0.01)$ & $(0.01)$ & $(0.01)$ & $(0.01)$ & $(0.01)$ & $(0.01)$ \\
\hline \multirow{2}{*}{$\ln ($ assets $)$} & $0.84^{* * *}$ & $0.84^{* * *}$ & $0.84^{* \star *}$ & $0.76^{\star * *}$ & $0.76^{* * *}$ & $0.76^{\star * *}$ \\
\hline & $(0.01)$ & $(0.01)$ & $(0.01)$ & $(0.01)$ & $(0.01)$ & $(0.01)$ \\
\hline \multirow{2}{*}{$\ln (1+$ age $)$} & $-0.35^{\star \star \star}$ & $-0.35^{\star \star *}$ & $-0.34^{\star \star \star}$ & $-0.24^{\star \star \star}$ & $-0.23^{\star \star \star}$ & $-0.23^{\star \star *}$ \\
\hline & $(0.03)$ & $(0.03)$ & $(0.03)$ & $(0.03)$ & $(0.03)$ & $(0.03)$ \\
\hline \multirow{2}{*}{$\frac{\text { TangibleAsset }}{\text { TotalAsset }}$} & $0.00^{\star \star *}$ & $0.00^{* \star *}$ & $0.00^{\star \star \star}$ & $1.00^{\star \star \star}$ & $1.00^{\star \star \star}$ & $1.00^{\star \star *}$ \\
\hline & $(0.00)$ & $(0.00)$ & $(0.00)$ & $(0.02)$ & $(0.02)$ & $(0.02)$ \\
\hline \multirow{2}{*}{$\frac{\text { Profit }}{\text { TotalAsset }}$} & $-0.08^{\star \star *}$ & $-0.08^{\star \star \star}$ & $-0.08^{\star \star \star}$ & $-0.06^{\star \star \star}$ & $-0.06^{\star \star \star}$ & $-0.06^{\star \star *}$ \\
\hline & $(0.00)$ & $(0.00)$ & $(0.00)$ & $(0.00)$ & $(0.00)$ & $(0.00)$ \\
\hline \multirow{2}{*}{ Bank Cap } & $0.07^{\star \star *}$ & $0.07^{* \star \star}$ & $0.05^{\star \star *}$ & $0.07^{* \star *}$ & $0.07^{\star \star *}$ & $0.05^{\star \star *}$ \\
\hline & $(0.00)$ & $(0.00)$ & $(0.01)$ & $(0.00)$ & $(0.00)$ & $(0.01)$ \\
\hline \multirow{2}{*}{ Bank Liq } & $0.01^{* \star *}$ & $0.01^{* * *}$ & $0.05^{\star * \star}$ & $0.01^{* * *}$ & $0.01^{* * *}$ & $0.04^{\star * *}$ \\
\hline & $(0.00)$ & $(0.00)$ & $(0.01)$ & $(0.00)$ & $(0.00)$ & $(0.01)$ \\
\hline \multirow{2}{*}{$\mathrm{h}$} & $-0.67^{\star \star \star}$ & $-0.67^{\star \star \star}$ & $-0.69^{\star \star \star}$ & $-0.63^{\star \star \star}$ & $-0.63^{\star \star \star}$ & $-0.65^{\star \star \star}$ \\
\hline & $(0.03)$ & $(0.03)$ & $(0.03)$ & $(0.03)$ & $(0.03)$ & $(0.03)$ \\
\hline \multirow{2}{*}{ Ratio } & $-2.55^{\star \star \star}$ & $-2.56^{\star \star \star}$ & $-2.56^{\star \star \star}$ & $-2.52^{\star \star \star}$ & $-2.53^{\star \star \star}$ & $-2.52^{\star \star \star}$ \\
\hline & $(0.02)$ & $(0.02)$ & $(0.02)$ & $(0.02)$ & $(0.02)$ & $(0.02)$ \\
\hline \multirow{2}{*}{ DR*Ratio } & & $0.16^{* \star \star}$ & $0.16^{\star \star \star}$ & & $0.14^{\star *}$ & $0.14^{\star *}$ \\
\hline & & $(0.05)$ & $(0.05)$ & & $(0.05)$ & $(0.05)$ \\
\hline \multirow{2}{*}{ call } & $-0.03^{\star \star *}$ & $-0.03^{\star * *}$ & $-0.01^{* *}$ & $-0.02^{* * *}$ & $-0.02^{\star \star *}$ & $-0.01^{*}$ \\
\hline & $(0.01)$ & $(0.01)$ & $(0.01)$ & $(0.01)$ & $(0.01)$ & $(0.01)$ \\
\hline \multirow{2}{*}{$\mathrm{DR}^{*}$ call } & $-0.01^{\star \star \star}$ & $-0.02^{\star \star \star}$ & $-0.02^{\star \star \star}$ & $-0.01^{\star \star \star}$ & $-0.02^{\star \star \star}$ & $-0.02^{\star \star \star}$ \\
\hline & $(0.00)$ & $(0.00)$ & $(0.00)$ & $(0.00)$ & $(0.00)$ & $(0.00)$ \\
\hline \multirow{2}{*}{ Bank Liq*call } & & & $-0.02^{\star \star \star}$ & & & $-0.01^{\star \star *}$ \\
\hline & & & $(0.00)$ & & & $(0.00)$ \\
\hline \multirow{2}{*}{ Bank Cap*call } & & & $0.01^{* \star *}$ & & & $0.01^{* * *}$ \\
\hline & & & $(0.00)$ & & & $(0.00)$ \\
\hline Wald statistics & $34,477.04$ & $34,497.70$ & $34,541.46$ & $38,848.83$ & $38,867.79$ & $38,879.15$ \\
\hline p-value & {$[0.00]$} & {$[0.00]$} & {$[0.00]$} & {$[0.00]$} & {$[0.00]$} & {$[0.00]$} \\
\hline group & \multicolumn{3}{|c|}{41,794} & \multicolumn{3}{|c|}{40,593} \\
\hline obs & \multicolumn{3}{|c|}{77,455} & \multicolumn{3}{|c|}{75,3221} \\
\hline
\end{tabular}

Previous analyses focused on whether firm- and bank-level characteristics play a significant role in deciding a firm's borrowing. In the following section, we investigate whether the interest rate is also an important determinant of a company's borrowing, along with bank and firm-level characteristics.

We use the policy rate as a proxy for the interest rate since the data used in this study do not provide information on the interest rate applied to each firm. We also introduce an additional independent variable, Ratio, which indicates 
how a firm's borrowing is concentrated on non-financial institutions or the share of firm borrowing from non-financial institutions. This variable can also represent the substitution effect of bank loans from financial institutions to non-financial institutions due to access difficulty or high cost of borrowing or other reasons. In addition to Ratio, we also include its interaction term with default risk since the former can also reflect the substitution effect of bank lending between financial institutions and non-bank financial institutions.

The results are reported in <Table $5>$ and indicate that Ratio has a negative and statistically significant impact, which means that more lending from non-financial institutions leads to decreased lending from financial institutions. In other words, the lending from non-financial institutions may substitute the demand for loans from financial institutions. The sign on the interaction term is positive and suggests that risky firms tend to borrow more from financial institutions when Ratio is the same.

The empirical analysis suggests that both bank-and firm-level characteristics are crucial factors in deciding the bank lending to firms. It also shows that increased firms default risk contributed to the decline in lending during the sample period. In the next section, we provide additional evidence that the default risk has changed during the sample period and confirm the results of our empirical analysis.

\subsection{Additional Evidence from Survey Data}

The empirical analysis suggests that firm-level characteristics along with bank-level characteristics are significant factors in deciding the size of loans that firms obtain from banks. We have also shown that a firm's default risk has a considerable influence, and the size of borrowing by companies with a substantial default risk is smaller than that of firms not expected to default. However, risky firms can offset this effect through their relationship with the bank and mitigate the adverse effect of default risk on borrowing starting a relationship with more liquid banks. The results also suggest that the decline in a firm's borrowing increases with default risk through its impact on the interest rate.

In the following section, we investigate whether corporate risk, measured by default risk, has increased indeed during the sample period. The Ministry of SMEs and Startups provides data on the default rates and how default risk has changed over time. <Figure $3>$ shows the trend in default risk by firm size. The solid blue line indicates the default risk significantly increased after 2008. The default risk of SMEs reached $2.7 \%$ in 2009 , four times greater than that of large firms. Even though the risk levels are somehow different between SMEs and large firms, all companies faced more severe default risk than before based on this index. This supports our empirical findings that firms borrowing from banks declined due to default risk during the sample period.

One may question whether the increased default risk results in less demand for loans and, hence, contributes to the decrease in the amount of lending. The Ministry of SMEs and Startups provides additional information based on survey data, which describes the willingness of SMEs to borrow, their demand for loans, and financial distress. By combining the trend of these ind with the default risk, we can rearm the findings from our empirical analysis.

We first examine whether the demand for loans has declined during the sample period. If the loan demand decreased along with the default risk, we can conclude that the drop in lending is due to the lack of demand for loans. Otherwise, we can confirm our findings, which suggest that the overall lending has dropped due to the default risk of firms, even in the presence of positive and greater loan demand than before the crisis.

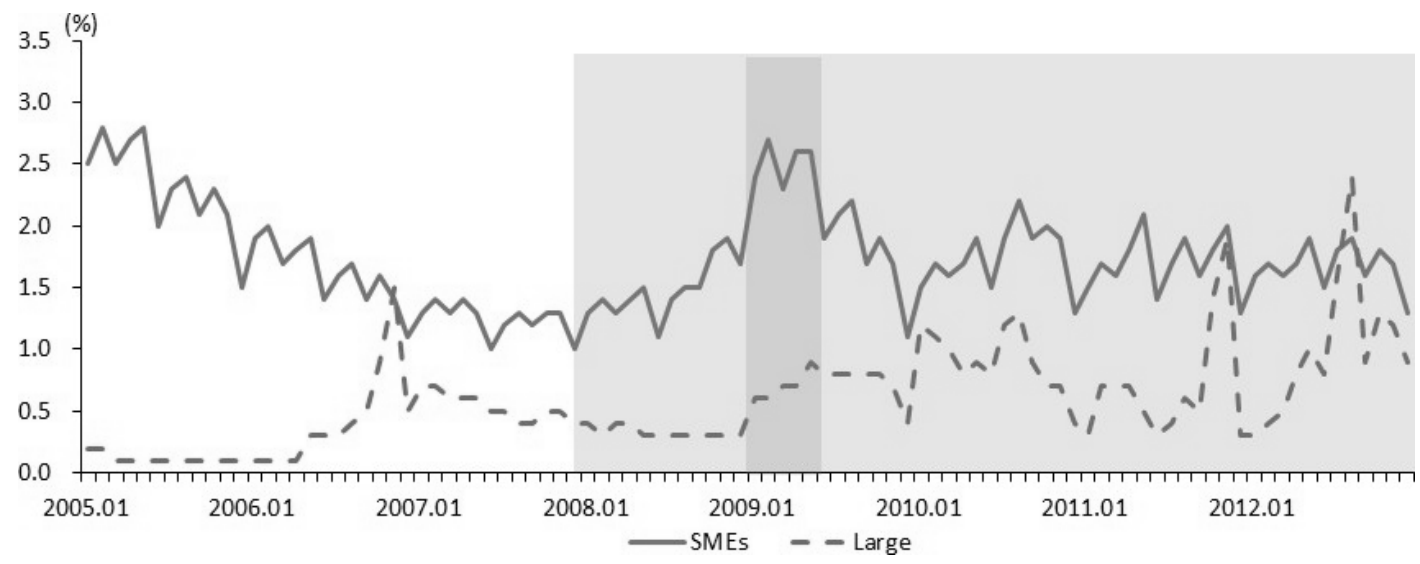

<Figure 3> Default Risk of Firms by Firm Size 
$<$ Table 6> Prospect of Demand for Finance

\begin{tabular}{|c|c|c|c|c|c|c|c|c|c|c|c|c|}
\hline \multicolumn{13}{|c|}{ (Unit: \%) } \\
\hline & 2001 & 2002 & 2003 & 2004 & 2005 & 2006 & 2007 & 2008 & 2009 & 2010 & 2011 & 2012 \\
\hline Manufacturing SMEs & 49.0 & 48.4 & 55.7 & 57.8 & 47.7 & 48.9 & 45.1 & 48.4 & 49.5 & 52.9 & 54.1 & 37.3 \\
\hline -Small & 48.0 & 50.4 & 54.2 & 59.5 & 50.2 & 47.0 & 45.7 & 48.9 & 50.8 & 53.4 & 53.1 & 35.9 \\
\hline -Medium & 50.5 & 45.4 & 58.9 & 54.7 & 42.0 & 52.9 & 43.8 & 47.2 & 42.6 & 50.0 & 58.1 & 43.1 \\
\hline
\end{tabular}

Source: Ministry of SMEs and Starups.

Note: Areas are shaded between specified date ranges to highlight periods of economic recession.

$<$ Table $7>$ Causes of Financial Distress for SMEs

\begin{tabular}{|c|c|c|c|c|c|c|c|c|c|c|c|c|c|}
\hline \multicolumn{14}{|c|}{ (Unit: \%) } \\
\hline & 2000 & 2001 & 2002 & 2003 & 2004 & 2005 & 2006 & 2007 & 2008 & 2009 & 2010 & 2011 & 2012 \\
\hline Manufacturing SMEs & 9.8 & 7.1 & 6.7 & 7.4 & 9.3 & 4.3 & 6.8 & 8.3 & 13.2 & 12.2 & 9.8 & 17.9 & 10.6 \\
\hline -Denied by Financial institutions & 6.1 & 3.9 & 4.3 & 4.4 & 7.5 & 2.4 & 3.1 & 2.0 & 5.8 & 4.7 & 5.9 & 7.3 & 2.1 \\
\hline -Increase in cost & 3.7 & 3.2 & 2.4 & 3.0 & 1.8 & 1.9 & 3.7 & 6.3 & 7.4 & 7.5 & 3.9 & 10.6 & 8.5 \\
\hline Medium & 10.2 & 5.5 & 7.2 & 7.0 & 5.2 & 5.4 & 8.5 & 13.5 & 12.4 & 16.7 & 8.5 & 13.5 & 14.0 \\
\hline -Denied by Financial institutions & 5.7 & 3.3 & 6.3 & 4.2 & 4.0 & 1.8 & 3.2 & 3.4 & 5.7 & 4.8 & 6.1 & 3.0 & 4.0 \\
\hline -Increase in cost & 4.5 & 2.2 & 0.9 & 2.8 & 1.2 & 3.6 & 5.3 & 10.1 & 6.7 & 11.9 & 2.4 & 10.5 & 10.0 \\
\hline Small & 9.7 & 7.8 & 6.6 & 7.6 & 10.6 & 3.9 & 6.2 & 6.4 & 13.3 & 11.8 & 9.9 & 18.6 & 9.3 \\
\hline -Denied by Financial institutions & 6.3 & 4.1 & 3.8 & 4.5 & 8.6 & 2.6 & 3.1 & 1.5 & 5.8 & 4.7 & 5.8 & 8.1 & 1.4 \\
\hline -Increase in cost & 3.4 & 3.7 & 2.8 & 3.1 & 2.0 & 1.3 & 3.1 & 4.9 & 7.5 & 7.1 & 4.1 & 10.5 & 7.9 \\
\hline
\end{tabular}

We use the survey data regarding the prospect demand for loans (or financing) as a proxy for firms demand for loans. This survey asks respondents about their prospect need for further funding compared to the previous year. The answers are classified into five categories, as follows: (1) significant increase, (2) slight increase, (3) no change, (4) slight decrease, (5) significant decrease. We then calculate the ratio of the number of firms that answered (1) and (2) to the total number of firms and use it as a proxy for loan demand.

<Table 6> shows the results for SMEs, especially for those in the manufacturing industry.

The share of firms that expects higher demand for loans did not decrease in 2008 and 2009 but increases after 2009 meaning that demand for loans remained at high levels after the financial crisis.

To summarize, SMEs demanded more loans than before during the financial crisis, but their borrowing could not increase because of the increase in their default risk.

$<$ Table $7>$ shows additional evidence from the survey. This survey asks firms the reasons why they cannot raise funds from financial institutions. SMEs in the manufacturing sector report financial distress due to the unwillingness of banks to lend and increased costs after 2011.

The empirical analysis and survey from the Ministry of SMEs and Startups confirm that firms demand for loans remained high during and after the crisis but the increased default risk did not allow companies to borrow more than before.

\section{Conclusion}

This paper investigates the determinants of bank lending to firms using firm- and bank-level data. The results show that companies borrow more from liquid banks, and high bank capital can also contribute to an increase in a firm's borrowing from banks. Firm-level characteristics, such as firm size and age, also have a significant impact on lending, as well as a firm's default risk.

The data show that the default rate has increased during and after the global financial crisis, which supports our empirical findings that default risk interplays with other firm and bank-level characteristics. The data and empirical findings suggest that default risk has an additional effect on the decrease in bank lending through bank capital, bank liquidity, relationship banking, and interest rate.

\section{References}

Banna, H., Ahmad, R., \& Koh, E. (2017). Determinants of Commercial Banks' Efficiency in Bangladesh: Does Crisis Matter?. Journal of Asian Finance, Economics, and Business, 4, 19-26.

Bernanke, B. S., \& Gertler, M. (1995). Inside the black box: The credit channel of monetary policy transmission. Journal of Economic Perspectives, 9(4), 27-48. 
Ferrarini, B., Hinojales, M., \& Scaramozzino, P. (2017). Chinese Corporate Leverage Determinants. Journal of Asian Finance Economics and Business, 4(1), 5-18.

Fukuda, S. I., Kasuya, M., \& Nakajima, J. (2006). Deteriorating bank health and lending in Japan: Evidence from unlisted companies undergoing financial distress. Journal of the Asia Pacific Economy, 11(4), 1-25.

Gertler, M., \& Gilchrist, S. (1994). Monetary Policy, Business Cycles, and the Behavior of Small Manufacturing Firms. The Quarterly Journal of Economics, 109(2), 309-340.

Jimnez, G., Ongena, S., Peydr, J. L., \& Saurina, J. (2012). Credit supply and monetary policy: Identifying the bank balance-sheet channel with loan applications. American Economic Review,
102(5), $2301-2326$.

Kim, S. C., \& Kim, J. Y. (2007). Lines of credit, borrowing costs, and relationship banking: Evidence from korean main credit banks. Asia-Pacific Journal of Financial Studies, 36(1), 1-32.

Liu, W. S., \& Sohn, K. W. (2015). The Price of Risk in the Korean Stock Distribution Market after the Global Financial Crisis. Journal of Distribution Science, 13(5), 71-82.

Mishkin, F. S. (1996). The channels of monetary transmission: Lessons for monetary policy (Working Paper No. 5464). National Bureau of Economic Research.

Rajan, R., \& Zingales, L. (1998). Financial dependence and growth. American Economic Review, 88(3), 559-86. 